SCHEDULES TO WHICH THIS ACT REFERS. SOHEDULA (A.)

THE MEDICAL REGISTER FOR ENGLAND,

Consisting of the Names, Qualifications, with the Dates thereof, and

Places of Residence, of all Persons legally authorized to practise Medicine in England and Wales in 1848.

\begin{tabular}{|c|c|c|}
\hline NAMES. & $\begin{array}{l}\text { QUALIFICATIONS, } \\
\text { AND THEIR DATES. }\end{array}$ & PLACES OF RESIDENCE. \\
\hline Addison, James Price \{ & $\begin{array}{l}\text { Degree of M.D. from the } \\
\text { University of Edinburgh, } \\
\text { dated August, } 1830 \text {. }\end{array}$ & $\begin{array}{l}\text { No. 16, Tudor-street, } \\
\text { Manchester. }\end{array}$ \\
\hline Adlard, Hugh .. & $\begin{array}{l}\text { Diploma as Fellow of the } \\
\text { Royal College of Sur- } \\
\text { geons, Ireland, dated } \\
\text { June, 1844. }\end{array}$ & $\begin{array}{l}\text { No. } 7 \text {, Milton-street, } \\
\text { Hanover-square, } \\
\text { London. }\end{array}$ \\
\hline Admonds, Richard & $\begin{array}{l}\text { Licence of the Society of } \\
\text { Apothecaries, London, } \\
\text { dated March, 1834. }\end{array}$ & $\begin{array}{l}\text { No.19, Millsom-street, } \\
\text { Exeter. }\end{array}$ \\
\hline Adney, Ralph ... & $\begin{array}{l}\text { Licence of the Royal Col- } \\
\text { lege of Physicians, Lon- } \\
\text { don, dated April, } 1839 .\end{array}$ & $\begin{array}{l}\text { No. } \mathbf{5 4} \text {, Holland- } \\
\text { street, Liverpool. }\end{array}$ \\
\hline Adpart, Erasmus .. & $\begin{array}{l}\text { Diploma as Member of the } \\
\text { Royal College of Sur- } \\
\text { geons of England, dated } \\
\text { November, } 1843 \text {. }\end{array}$ & $\begin{array}{l}\text { No.40,Tollville-street, } \\
\text { Leeds. }\end{array}$ \\
\hline Adwin, Gilbert ... & $\begin{array}{l}\text { Declaration, as required by } \\
\text { the Act, of having prac- } \\
\text { tised as an Apothecary } \\
\text { before 1st August, } 1815 \text {. }\end{array}$ & $\begin{array}{l}\text { The Grove, Camber- } \\
\text { well, Surrey. }\end{array}$ \\
\hline
\end{tabular}

\section{Scheddle (B.)}

Declaration required of a person who claims to be registered an APOTHECARY upon the ground that he was in practice as an Apothecary before the first day of August, 1815.

To the Medical Registrar for England.

I [Samuel Baker], residing at [6, Duke-street, Exeter, in the county of [Devon], hereby declare that I was practising as an Apothecary at [16, George-street, Hastings, ] in the county of [Sussex,] before the 1st day of August, 1815 .

(Signed)

[Samuel Baker.]

Dated this [6th] day of [October] 1847.

\section{SCHEDULe (C.)}

THE MEDICAL REGISTER FOR ENGLAND.

\section{Registration Certificate for 1848 .}

By virtue of the powers vested in me by an Act of Parliament passed in the eleventh year of the reign of her Majesty Queen Victoria, intituled, "An Act for the Registration of Qualified Medical Practitioners, and for amending the law relating to the Practice of Medicine in Great Britain and Ireland;" I hereby certify, that [JAwrs HowARD], residing at [15, Ormond-street, Manchester;] in the [county of Lancaster,] has been duly registered according to the provisions of the said Act, as a person who is qualified to practise medicine in any part of England and Wales, and that he is entitled to exercise all the powers and privileges conferred by the said Act.

This certificate to remain in force until the 31 st day of December [1848,] and no longer.

\section{(Signed) [Henry Brown, ]}

Dated, London, 6 October, 1848.

Medical Registrar for England.

\section{THE SOCIETY OF APOTHECARIES AND THEIR ACT OF 1815.}

The following extraordinary statement has just been published by the Society of Apothecaries. After having caused sundry prosecutions, and professed to carry the Act of 1815 into execution, the sapient wiseacres who govern the affairs of the Society have been obliged, at the end of thirty-two years, to apply to three barristers to ascertain what are really the provisions of that law under which they have been exercising their functions during the third part of a century. Such is the capacity of persons who have dared to institute prosecutions against others, not being unqualified quacks and impostors, but graduates of universities, and highly educated members of the medical profession, because their victims did not understand the provisions of the statute of 1815 . On this extraordinary statement, particularly the last paragraph, we shall offer some comments in an early number of The Lancet. The master and wardens of the Worshipful Society had to apply to the attorney-general to ascertain whether it was a misdemeanor to violate the penal provision of the fifty-fifth George III. Poor simpletons! But now, having learned that the offence really is a misdemeanor, are they prepared to punish the delinquents? In order to obtain an answer, look at the last paragraph. We really have no patience with such beings; they are even beneath contempt.

"The Society of Apothecaries entertaining an opinion, which they have publicly expressed upon several occasions, that a penal check upon the practice of medicine by unqualified persons is indispensably necessary for the protection of the public, and that the pecuniary penalty imposed by the Apothecaries' Act is but ill adapted for checking such practice, have long desired that a more summary mode of proceeding against illegal practitioners should be adopted; and they have advocated an alteration of the law in this respect, whenever a favourable opportunity for so doing has presented itself. A recent decision of the Court of Queen's Bench, in a criminal prosecution instituted against an attorney for practising without qualification, seemed to lead to the conclusion, that not. withstanding the specific pecuniary penalty imposed upon unqualified persons practising as apothecaries, such persons might be indicted criminally as for a misdemeanor. This decision appeared to the Society to suggest a mode of proceeding for checking the illegal practice of medicine, which might be attended with such important results, that they determined to lose no time in obtaining the highest legal opinions upon the subject. They therefore laid a case before the law officers of the crown, and it will be found, from the answers given to the questions submitted to the Attorney and Solicitor General, in consultation with Mr. F. Robinson, that it is the opinion of those learned gentlemen that an indictment will lie against a person who has practised as an apothecary without legal qualification. The Society subjoin the questions proposed to counsel, and their answers thereto.

\section{Qonstions.}

1. Whether an indictment will lie against a person who has practised as an apothecary without legal qualification, notwithstanding the particular penalty imposed upon persons so practising by the 20 th section of the Act, and the disability imposed upon them by the 21st section? and if you should be of opinion that an indictment will lie?

2. In what courts, metropolitan or provincial, could such an indictment be preferred? and could it be preferred at the instance of a private prosecutor?

3. Would it be competent for the Society of Apothecaries to prefer such an indictment, notwithstanding the interest given to the Society in the pecuniary penalties imposed by the 20 th section, and the particular remedy given to the Society for the recovery of such penalties?

4. What would be the extent of punishment which could be inflicted by law upon a person convicted of the offence of practising as an apothecary without legal qualification ?

5. Can any more summary proceeding than an indictment be resorted to for the punishment of persons practising as apothecaries without legal qualification?

\section{ANswers.}

1: We think that an indictment will lie against a person who has practised as an apothecary without legal qualification, notwithstanding the particular penalty imposed by the 20 th section of the Act, and the disability imposed by the 21st section.

2. The indictment may be preferred in any of the ordinary criminal courts having cognizance of misdemeanors committed in the county or place in which the party has so illegally practised, and it may be preferred at the instance of a private prosecutor. 
3. We think it is competent for the Society of Apothecaries to prefer the indictment.

4. The punishment, as in case of other misdemeanors, would be fine or imprisonment, or both, at the discretion of the court.

5. We are not aware that any more summary proceeding than an indictment can be resorted to, for the punishment of persons practising as apothecaries without legal qualification.

JoHN JERVIS,

David Dundas,

Temple, Nor. 23.

Frederic Robinson.

It is perhaps hardly necessary for the Society to point out the increased facilities which this mode of proceeding affords for putting the law in force against unqualified practitioners.

Instead of proceeding for the recovery of penalties by a civil action, which in the case of a country practitioner could only be tried at the spring and summer assizes, an indictment may be preferred at the quarter sessions and at the assizes also; and instead of the power of proceeding against unqualified practitioners being restricted, as in the case of the specific penalty imposed by the statute, to the Society of Apothecaries, it will be competent for any person to prefer an indictment who may be disposed to do so.

Another distinction between the two modes of proceeding, which is likely to operate still more powerfully as a check upon illegal practice, is this, that whereas an individual against whom a judgment for a penalty is obtained, under the present form of proceeding, can relieve himself from the consequences of his offence by obtaining his discharge under the bankrupt or insolvent Acts, an individual found guilty on indictment of having practised as an apothecary without legal qualification will be punishable by fine and imprisonment, and will have to undergo whatever measure of punishment the Criminal Court may in its discretion award.

The Society sincerely hope that a public intimation that the penalties of the law can now be enforced against illegal practitioners of medicine more summarily than heretofore, will deter all persons from practising as apothecaries who have not given such evidence of their competency to practise as the law demands. But if individuals, who have not possessed themselves of a legal qualification, will persist in practising in the absence of such qualification, they will do so at the risk of being criminally indicted for the offence at the instance of any individual prosecutor who may be induced to prefer an indictment against them.

The Society, on their part, will be ready, as they have ever been, to enforce the law to the extent of the means placed at their disposal, but those means are inadequate to the institution of frequent prosecutions. It may therefore be anticipated, that indictments will be preferred at the instance of other parties; and the Society take this opportunity of stating, that they will endeavour to render such experience as they may have acquired in administering the Act of 1815 available in furthering the ends of justice; and that they will be prepared, upon proper application, to furnish any information, in connexion with the subject of illegal practice, which they may have it in their power to afford.

Apothecaries' Hall, Dec. 10.

\section{Corresponouence.}

\section{THE HOUNSLOW FLOGGING CASE. (LETTER FROM MR. RRASMUS WILSON.)}

To the Editor of The Lancer.

SIR,- - In your journal of last week is published a letter from Mr. Day, of Isleworth, purporting to be a reply to a remark of mine contained in ThE LANCET for Dec. 12th. The remark is as follows:- " I have now to allude to a disingenuous attempt on the part of $\mathrm{Mr}$. Day to throw discredit on my testimony. Mr. Day observed in his written report-_ The softening of the muscular fibre had extended into the intercostal muscles immediately subjacent, but had not penetrated the internal intercostals.' Your readers will perceive the ready answer which this attempt at the mystification of truth drew forthnamely, that there was no internal intercostal muscle in the situation referred to-that is, near the heads of the ribs." In his reply, Mr. Day admits himself to have been in error in respect of the anatomical question, but avails himself of the opportunity which his letter affords of making a series of trivial accusations against me. Under ordinary circumstances, $I$ should not have thought it necessary to have taken any notice of Mr. Day's reproaches, but in reference to the part which duty to my Queen and mine own honour obliged me to take in the Hounslow inquiry, I an anxious for the strictest investigation.

It was not without careful deliberation that $I$ applied the term "disingenuous" to Mr. Day's attempt to invalidate my testimony; and in attributing to him a "mystification of the truth," I was not induced by his anatomical mis-statement alone, but equally by the unnsual and indecorous course which he pursued of criticizing the evidence of a fellow-witness. For example, he gratuitously informed the court that in my evidence I "drew upon my imagination." How far I may have been imaginative in my views, I may safely leave to the judgment of your readers. Again, he styles my explanation of the morbid condition of the muscles "mere conjecture." That these were proper epithets to be applied to evidence given honestly and truthfully before a jury for their guidance, I cannot be made to believe; and the course taken by Mr. Day was in my opinion, to say the least, disingenuous. The occasion of using the words "mere conjecture" is curiously in discord with the sentiments expressed in his present letter. It is as follows:"The cause of the change of the muscles is a mere matter of conjecture." (THE LANCET, Aug. 15th.) Whereas, in his letter of Dec. 15th, Mr. Day remarks-" We perfectly agreed in the supposition that the morbid state had been produced, either by violent spasmodic action, causing laceration of the muscular fibres, or that some of the fasciculi had been torn," \&c.

Mr. Day's first accusation against me is, that the opinion given to him by me on the day of examination of the spine of the deceased "was greatly at variance with the evidence" which I subsequently gave to the coroner. Permit me to explain:-

On Wednesday, July 22nd, being very much out of health, I went to Heston, to make, in conjunction with Mr. Day, the post-mortem examination in question. The operation lasted about four hours, and the duty, performed in a churchyard, under a hot July sun, with no awning, and the subject twelve days deceased, was one of no little trial and labour. On concluding the investigation I was much exhausted, and not at all in a condition to arrange my thoughts into the form of an opinion upon the mutual bearings of the morbid appearances. Moreover, being very much engaged about that time, in preparing a work for the press, I had not seen the newspapers, and knew nothing of the previous history of the case. I learnt, from Mr. Day, that there had been pleuritis and other inflammation of the thoracic viscera, but the exact morbid appearances presented by the interior of the body $I$ did not know until I heard them at the adjourned inquest on the succeeding Monday. I therefore was not in a position to form an opinion on that day, nor did I attempt to do so until I had had the advantage of an evening's thought, and had refreshed my mind by a night's sleep. Whatever I may have imparted to $\mathrm{Mr}$. Day in the way of medical conversation is altogether beside the question; I had not formed an opinion for myself and could therefore give none to him. But I did one thing, I wrote the facts of the examination on paper, and gave the document to Mr. Day, making a copy thereof for myself; and after Mr. Day had approved the statement therein made, we both signed them. In parting with $\mathrm{Mr}$. Day, I promised that I would put the facts into a popular shape, so as to be more suitable for a non-medical jury, and send them to him previously to the inquest, for his further approval and signature. This promise I did not think it necessary to fulfil until the day of the inquest, because the facts were unchanged; I simply made them more precise, and amplified the details. I had another reason for preferring to show the statement to $\mathrm{Mr}$. Day personally, which was, that $I$ had added opinions to the Report. And as I conceive that no man can be held responsible for the opinions of another, I did not think it just to expect Mr. Day to affix his signature to opinions which, as he truly says, he saw then for the first time. In pursuing this course, $I$ conceived that I was adopting one dictated by the highest sense of honour. Mr. Day seems to think that I excluded his signature from that report for the purpose of arrogating to myself the honour of what he terms, a "discovery." My true object was, to save him from the responsibility of opinions which might not have been, and as I believed were not, his own.

There is an impression, which pervades the whole of Mr. Day's letter, that there should have been a consultation and an agreement of opinion between us, against which I most strongly protest. We were independent witnesses, united for a moment in an inquiry into facts, but totally separate and distinct, and perfectly free agents as respects conscience and opinion. I look upon it that Mr. Day could have adduced no 